INTERNATIONAL JOURNAL OF RESEARCHES IN BIOSCIENCES, AGRICULTURE AND TECHNOLOGY

(c) VISHWASHANTI MULTIPURPOSE SOCIETY (Global Peace Multipurpose Society) R. No. MH-659/13(N) www.ijrbat.in

\title{
RESPONSE OF SOME PLANT GROWTH REGULATORS ON GROWTH OF CONIDIA OF ALTERNARIA BRASSICICOLA (BERK.) WILTSHIRE.
}

\author{
M.N. Bhajbhuje \\ Department of Botany \\ Jawaharlal Nehru Mahavidyalaya, Wadi, Nagpur : 440023 (M.S.) India. \\ e-mail : dr_mnbhajbhuje@rediffmail.com
}

\begin{abstract}
:
Response of some plant growth regulators was studied in-vitro against leaf blight pathogen of cauliflower, Alternaria brassicae (Berk.) Sacc. All test chemical inducers significantly reduced spore germination and germling growth of pathogen at $10^{-2}$ to $10^{-4}$ Mconc. Test pathogen exhibited sensitive response against $10^{-2}$ conc. of naphthalene acetic acid, reducing spore germination by $86 \%$ and germ tube growth by $14 \%$ over untreated control. Moreover, all test chemical inducers at $10^{-1} \mathrm{M}$ conc had absolute inhibitory effect on spore germination of pathogen. Indol-3-acetic acid had least inhibitory effect against test pathogen of these parameters undertaken. The results revealed possibility of usage plant growth regulators in inducing phytoalexin compound in susceptible plant cultivars, results to increase resistance against the leaf blight causing pathogen.
\end{abstract}

Keywords: Fungitoxicity, susceptible, pathogen, chemical plant resistance inducers

\section{INTRODUCTION:}

The ubiquitous fungal genus, Alternaria comprises diverse saprophytic as well as endophytic and is known for its notoriously destructive plant pathogen (Mamgain et al., 2013). It has been reported to have a drastic effect on the members belonging in the plant families such as Cucurbitaceae, Brassicaceae, Solanaceae, Poaceae etc. which are having nutritional as well as economical food value. It is associated with a wide variety of substrates including seeds, plants, agricultural products, animals, soil and the atmosphere. It is also common allergens in humans, growing indoors and causing hay fever or hypersensitivity reactions that sometimes lead to asthma. Some species readily cause opportunistic infections in immuno-compromised people such as AIDS patients (Mamgain et al., 2013)

The family Brassicaceae comprises a wide range of vegetable crop of economic, nutritional and nutraceutical importance (Reis and Boiteux, 2010). Brassica oleracea L. var. botrytis is one of the most widely cultivated type throughout the world. Foliar diseases are one of the most important limiting factors for cultivation of Brassicaceae. The fungus, Alternaria brassicicola (Berk.) Wiltshire, is a major pathogen being prevalent Brassica oleracia complex, caused rounded, well-defined, dark brown leaf spots with pale centre delimited by a chlorotic halo leaf spot resulting in defoliation, reduction in size and quality of fruits, ultimately adversely affects productivity (Reis and Boiteusl, 2010). The leaf spots may be control by foliar application of effective organic fungicides, but these are reported hazardous and their residual toxicity in plant parts, fruits poses carcinogenic disorders to consumers (Mamgain et al., 2013) and also helps to increase level of air pollutants. To overcome these, the concept of screening for disease resistance has been developed (Eckadt, 2011). Phytoalexin accumulation at infection site in leaves in response to treatment with certain chemicals (Ismile et al,, 1987 and Bhajbhuje, 2013) makes a significant contribution to resistance, cultivars that are normally susceptible to a virulent race of pathogen thus providing protection in different plants. A little is known about induction of resistance by application of plant growth regulators in plants and control of leaf blight pathogen, it seemed to be worthwhile to report the 
fungitoxicity of plant growth regulators at variable concentrations against leaf blight pathogen, Alternaria brassicicola (Berk.) Wiltshire.

\section{METHOD AND MATERIAL:}

The plant growth regulators of diverse chemical nature induce phytoalexin in plants, when applied in dilute concentration, were screened for fungitoxic assay against leaf spot causing pathogen Alternaria brassicicola (Berk.) Wiltshire. The various concentrations of ranged between $10-1$ to $10-4 \mathrm{M}$ for five plant growth regulators was prepared. Alternaria brassicicola was isolated from infested leaves as well as stored seeds of cauliflower and maintained in laboratory on PDA nutrient medium at $25 \pm 10{ }^{\circ} \mathrm{C}$. The various concentrations of test solutions were tested for fungitoxic assay employing slide germination technique (CMI, 2010). Germination of conidia was counted in terms of percentage on the basis of 300 spores and germ tube growth was measured on the basis of 90 germlings from each spot observed randomly.

\section{RESULTS AND DISCUSSION}

Altogether five plant growth regulators in conc. between $10-2$ to $10-4 \mathrm{M}$ are screened to study invitro fungitoxic effect on conidia germination and germ tube growth of pathogen employing slide germination technique (CMI, 2010).

Aqueous solution of all five plant growth regulators at different concentrations caused injury to spore of Alternaria brassicicola inhibiting conidia germination and germ tube growth. NAA and PAA induced absolute inhibition for both parameters when treated at $10-1 \mathrm{M}$ conc. NAA at 10-2M caused greater inhibitory effect, reducing conidia germination by $83 \%$ over untreated control, followed by PAA causing reduction in this parameter by 72 $\%$. Moderate inhibitory effect to the extent of $60 \%$ and $63 \%$ for conidium germination was recorded with 2, 4-D and IBA at 10-2M conc. respectively. IAA induced least inhibitory effect was reported at this conc. (Table 1).
The inhibitory effect for all the plant growth regulators was declined with decrease in concentration of test chemicals. The greatest declining of inhibitory effect was recorded with NAA, reducing spore germination by $35 \%$ and $13 \%$, when treated at conc. $10-3$ to $10-4 \mathrm{M}$. Least inhibition was confined at $10-4 \mathrm{M}$ with IAA while remaining test chemical inducers had considerable to moderate inhibitory effect (Table 1). The similar trend was reported for germ tube emergence with all concentration of test chemical inducers. The conidia of Alternaria brassicicola treated with all five test chemicals at $10-1 \mathrm{M}$ conc did not produce germ tube excepting IAA. The test chemicals excluding IAA had 8 to $17 \%$ inhibitory effect on germ tube growth at $10-2 \mathrm{M}$ compared to untreated control.

The inhibitory effect was declined with decrease in concentration of test chemicals. The greatest declining of inhibitory effect was recorded with PAA reducing the germ tube growth by $14 \%$ and $11 \%$ at conc. $10-3$ to $10-4 \mathrm{M}$ respectively. NAA induced $8 \%$ inhibition; remainings had mild effect at 10-4 M while IAA had little inhibitory effect compared to untreated control (Table 1).

Of the five plant growth regulators screened against Alternaria brassicilola, NAA caused greater inhibition of conidia germination, but had moderate inhibitory effect on germ tube emergence, while PAA induced considerable inhibitory effect on conidia germination but had greater reduction in germ tube growth. Moderate to considerable inhibitory effect was recorded with IBA and 2,4-D while IAA had least inhibitory effect on both parameters undertaken (Table1). Similar findings were reported with conidia of Alternaria tenuis (Bhajbhuje, 1989); A. tenuissima (Singh et al., 2000); A. solani (Abdel-Kader et al., 2012). The effectiveness of variable concentration of diverse group of chemicals was confirmed on conidia of Alternaria porae (Feofilova et al., 2012) and 
Alternaria alternata (Bhajbhuje, 2014). Ezzouhri et al., (2009) reported chemical tolerance level of some filamentous fungi including Alternaria alternata, Aspergillus niger, Geotrichum candidus, Penicillium sp. and Fusarium sp. The inhibition of conidia germination may be attributed to variable toxic effect of test chemicals.

The hydrolytic products of the chemicals possibly at low conc. induced dormancy or may cause injuries to fungal conidia by dissolving the protective thick wall layers and plasma membrane or ruptured them making porous. Aqueous solution of test chemicals diffused through ruptured cell wall and porous plasma membrane to cytoplasm, react with functional cytoplasmic components of conidia and seems to disturb a series of physiological processes of conidia germination leading to destruction of inhibitors of trehalose degrading enzymes; and shifting of a series of interlocking enzyme reactions. The enzyme is thought to be spatially separated from its substrate inside a dormant spores and activation may bring the two together (Feofilova et al., 2012). In the present studies, the variable inhibition of fungal conidia germination and germ tube growth may be attributed to the differential toxic effect of the test chemicals.

\section{CONCLUSION:}

The experimental findings reveal that an aqueous solution at $10-2 \mathrm{M}$ concentration of plant growth regulators seemed to provide more vigorous defence response to virulent pathogen, Alternaria solani. These phytoalexin inducer test chemicals stimulated production of large amount of fungitoxic substances in susceptible tissue on post-infection of virulent pathogen which make plant resistant to some extent and readily respond to infection. Of the test chemical inducers, naphthalene acetic acid at 10$2 \mathrm{M}$ may serve as very promising compounds for use in plant disease control.

\section{ACKNOWLEDGEMENT}

The author indebted the facilitation of this work by Principal, J.N. College, Wadi, Nagpur; Prof .R.P. Thakre, and Dr. T. Srinivasu, Prof. \& Head, P.G. Dept. of Botany, RTM, Nagpur University, Nagpur.

\section{REFERANCE :}

Abdel-Kader MM, El-Mougy NS, EI-Gannal NG, Abd-EI-Kareem F, Abd-Alla. 2012. Laboratory

evaluation of some chemicals affecting pathogenic fungal growth. Jour. Appl. Sci. Res., 8(1) : 523530.

Bhajbhuje MN. 1989. Investigations on mycoflora associated with vegetable seeds from VidarbhaRegion. Ph.D. Thesis, R.T.M. Nagpur University, Nagpur, M.S. India.

Bhajbhuje MN. 2013. Role of heavy metal salts on susceptibility of Solanum melongena L. seedlings to Alternaria early blight disease. Int. J. of Life Sciences, 1 (1) : 51-62.

Bhajbhuje MN. 2014. Response of heavy metal salts against Alternaria leaf spot infection on Vigna mungo (L.) Hepper seedlings by three techniques. Int. Jour. of Life Sci., 2(2): 1-13.

CMI. 2010. Commonwealth Mycological Institute. Description of Pathogenic fungi and bacteria. Kew Surrey, England. Pp 451-460.

Eckadt NA (2011). Induction of Phytoalexin Biosynthesis: WRKY ${ }_{33}$ - Is a Target of MAPK Singling. Plant Cell, 23(4) : 1190.

Ezzouhri L, Castro E, Moya M, Espinola F, Lairini K. 2009. Heavy metal tolerance of filamentous fungi isolated from polluted sites in Tangier, Morocco. African Jour. Microbiol. Res., 3(2) : 35-48. 
Feofilova E, Ivashechkin A, Alekhin A, Sergemma Y. 2012. Fungal spores: Dormancy, germination, chemical composition \& role in biotechnology (review), Appl Biochem, \& Microbiol., 48(1):1-21.

Ismile, IMK., Salama, AAM., Ali, MIA., Oaf, SAE 1987. Effect of some phenolic compounds on spore germination and germ tube growth of Asergillus fumigatus and Fusarium oxysporum f. sp lycopersici. Cryptogamie Mycology, 8(1) : 51-60.

Mamgain, A., Roychoudhary and Jagatpati Tah. 2013. Alternaria pathogenicity and its strategic controls. Res. Jour. of Biology, 1 : 1-9
Reis, A. and Boiteux 2010. Alternaria species infecting brassicaceae in the Brazilian Neotropics, geographical distribution, host range and specificity. Jour. Pl. Pathol., 92(3) : 661-668.

Singh SK, Singh UP, Tuli L, Prithviraj B , Sarma BK. 2000. Effect of spore conc, of Alternariatenuissima on germination \& development of germ tubes on hosts \& nonhosts. Indian Phytopath., 53(4) : 419-422.

Table 1: Effect of plant growth regulators at dilute concentration on spore germination and germ tube growth of Alternata bassicicola.

\begin{tabular}{|c|c|c|c|c|c|c|c|}
\hline \multirow[t]{2}{*}{$\begin{array}{c}\text { S.No } \\
\text {. }\end{array}$} & \multirow[t]{2}{*}{$\begin{array}{l}\text { Plant growth } \\
\text { regulators }\end{array}$} & \multicolumn{3}{|c|}{$\begin{array}{c}\text { Percent } \\
\text { spore germination }\end{array}$} & \multicolumn{3}{|c|}{$\begin{array}{c}\text { Mean } \\
\text { germ tube growth }\end{array}$} \\
\hline & & $10^{-2} \mathrm{M}$ & $10^{-3} \mathrm{M}$ & $10^{-4} \mathrm{M}$ & $10^{-2} \mathrm{M}$ & $10^{-3} \mathrm{M}$ & $10^{-4} \mathrm{M}$ \\
\hline 1. & $\begin{array}{l}\text { Indol-3-acetic acid } \\
\text { (IAA) }\end{array}$ & $\begin{array}{c}45 \\
(-54.1)\end{array}$ & $\begin{array}{c}73 \\
(-25.5)\end{array}$ & $\begin{array}{c}97 \\
(-1.0)\end{array}$ & $\begin{array}{c}92 \\
(-5.2)\end{array}$ & $\begin{array}{c}95 \\
(-2.1)\end{array}$ & $\begin{array}{c}96 \\
(-1.0)\end{array}$ \\
\hline 2. & $\begin{array}{l}\text { Indol-3-butyric } \\
\text { acid (IBA) }\end{array}$ & $\begin{array}{c}36 \\
(-63.3)\end{array}$ & $\begin{array}{c}66 \\
(-32.7)\end{array}$ & $\begin{array}{c}93 \\
(-5.1)\end{array}$ & $\begin{array}{c}87 \\
(-10.3)\end{array}$ & $\begin{array}{c}91 \\
(-6.2)\end{array}$ & $\begin{array}{c}93 \\
(-4.1)\end{array}$ \\
\hline 3. & $\begin{array}{c}\text { Naphthalene acetic } \\
\text { acid (NAA) }\end{array}$ & $\begin{array}{c}17 \\
(-82.7)\end{array}$ & $\begin{array}{c}49 \\
(-50.0)\end{array}$ & $\begin{array}{c}85 \\
(-13.3)\end{array}$ & $\begin{array}{c}84 \\
(-13.4)\end{array}$ & $\begin{array}{c}88 \\
(-9.3)\end{array}$ & $\begin{array}{c}89 \\
(-8.2)\end{array}$ \\
\hline 4. & $\begin{array}{l}2,4- \\
\text { dichlorophenoxy } \\
\text { acetic acid }(2,4-\mathrm{D})\end{array}$ & $\begin{array}{c}39 \\
(-60.2)\end{array}$ & $\begin{array}{c}69 \\
(-29.6)\end{array}$ & $\begin{array}{c}96 \\
(-2.0)\end{array}$ & $\begin{array}{c}89 \\
(-8.2)\end{array}$ & $\begin{array}{c}94 \\
(-3.1)\end{array}$ & $\begin{array}{c}96 \\
(-1.0)\end{array}$ \\
\hline 5. & $\begin{array}{c}\text { Phenyl acetic acid } \\
\text { (PAA) }\end{array}$ & $\begin{array}{c}27 \\
(-72.4)\end{array}$ & $\begin{array}{c}57 \\
(-41.8)\end{array}$ & $\begin{array}{c}89 \\
(-9.2)\end{array}$ & $\begin{array}{c}80 \\
(-17.5)\end{array}$ & $\begin{array}{c}83 \\
(-14.4)\end{array}$ & $\begin{array}{c}86 \\
(-11.3)\end{array}$ \\
\hline & Water (Control) & 98 & 98 & 98 & 97 & 97 & 97 \\
\hline \multicolumn{8}{|c|}{$\begin{array}{l}\text { 1. Results have been expressed as percentage in terms of control; } \\
\text { 2.Average of } 300 \text { spores; 3.Average of } 90 \text { germlings; } \\
\text { in parentheses indicate percentage reduction or increase in terms }\end{array}$} \\
\hline
\end{tabular}


